\title{
Women domination in the Galombang dance: between the customary idealism and the market use
}

\author{
Indrayuda, Ardipal \\ Department of Drama, Dance and Music, Faculty of Languages and Arts, \\ Universitas Negeri Padang, Indonesia
}

Received: August 11, 2017. Revised: October 18, 2017. Accepted: December 3, 2017

\begin{abstract}
This study aims to answer the women dominance in the Galombang dance creation in Minangkabau, West Sumatra from gender perspective. In addition, this study also reveals the position of women as an urgent thing in the Minangkabau dance creations, Galombang. This research used interdisciplinary approach, namely Cultural Sociology and Dance Anthropology. The data were obtained through various interviews, direct monitoring in the situation of the Galombang dance activity, and literature study to support the primary data. The analysis was done through ethnography method. The result of the research found that women dominance was bigger than men in the Galombang dance creations. In customary idealism, women are not Galombang dancers as the Galombang dance is intended for men. In reality, there is a bigger role between men and women in the Galombang dance; therefore, men's role is not very decisive on the performance quality and selling value, as well as for the use of dance Galombang creations by society nowadays in West Sumatra.
\end{abstract}

Keywords: women domination; gender; customary idealism; the Galombang dance creation

How to Cite: Indrayuda \& Ardipal. (2017). Women domination in the Galombang dance: between the customary idealism and the market use. Harmonia: Journal of Arts Research And Education, 17(2), 153-162. doi:http://dx.doi.org/10.15294/ harmonia.v17i2.10724

\section{INTRODUCTION}

In Minangkabau philosophy, women are termed "limpapeh rumah nan gadang, sumarak dalam nagari, hiasan di dalam kampuang, nan tahu jo malu dan sopan, nan kamahias kampuang jo halaman, hiasan dunia jo akhiraik, kok auih tampek minta aia, lapa tampek minta nasi" (Jamal, 2011). It means that women are an elevated human figure in the clan, and women hold role as a symbol of family self-esteem as well as a village and country decorations. In addition, women are expressed as a human figure who upholds politeness and respectful.
Rinaldi (2013) says that women's position in Minangkabau is as the main pillar in a household. Aside from being the main pillar (limpapeh), women are also the caretakers of heritage treasures, and Minangkabau women are taught to be independent at home. Therefore, in the past, women were not justified in performing art performances shown to public such as Randai players, and Silek Galombang. Although there was a female character in Randai, it was still played by men. As the main pillar of the gadang or family house, the woman's dignity needs to be maintained for not being blameworthy as well as kee-

\footnotetext{
${ }^{\square}$ Corresponding author: Jl. Prof. Dr. Hamka Air Tawar Padang

E-mail: indrayudayusuf@yahoo.co.id
} 
ping the pole from collapsing as the result of the disgrace done by the woman. Therefore, activities that will bring disgrace to women were forbidden for her to involve in such activities.

For Minangkabau society, art is as a pamenan (game) and a cultural heritage cultivated long before the colonial era entered Minangkabau territory. An example of that art is Galombang or silek Galombang. The Galombang Dance or silek Galombang is traditionally danced by men. Male in the Galombang dance exists along with the base of the dance that grows and develops in the target of pencak silat (Indrayuda, 2009). Customarily, pencak silat is intended for men as well as art within the target, thus the Galombang dance (also called silek Galombang) as part of pencak silat is an activity for Minangkabau men.

The Galombang Dance as a tradition dance in Minangkabau essentially is used to guard and protect guests as well as respect it. The Galombang dance movement is derived from the parts of silat moves existing in the nagari where martial arts grow. The Galombang dance movement is in accordance with martial arts' flow in the original nagari of the Galombang dance. Thus, as the Galombang dance is a martial arts representation, the Galombang dance is performed by men.

Nerosti (2013) says that the Galombang dance is one of the traditional Minangkabau dances owned by every nageri (village) community in Minangkabau (West Sumatra). The Galombang Dance is always performed at reception ceremony of the respected guests such as traditional chief or penghulu, martial arts teacher, and bride. The Galombang dance is performed by several male dancers with the pattern of the two-lined floor going backwards. There are two kinds of presentation, one direction only and two directions. This means that traditional Galombang dance is performed by men.

Globalization has brought an impact on the emergence of the entertainment and tourism industry in West Sumatra. Tourism and Entertainment Industry also has have led to the emergence of dance creations created by dance artists from various production houses in West Sumatra. The new dance has shifted the existence of traditional dance that has become the cultural heritage of Minangkabau society. Nowadays, local artists and custom elites feel restless with this development as the Minangkabau dance rule has shifted. But in the form of Minangkabau dance, it has developed in quality as happens in the dance of Galombang creations (Indrayuda, 2016).

Iriani (2012) says that the result of social change in West Sumatra impacts on the rules and the order of Minangkabau dance tradition. In general, many Minangkabau dance creations such as the Galombang dance and the Ilau dance, have shifted its order and rules. The essence of the shifting order and rules has led to the change of customary values in the dance, yet the dance creation is preferred by consumers of performing arts.

The male role reality in the Galombang dance traditionally in nagari has been eliminated with the dominance of women as dancers of the Galombang creations nowadays. This trend austerely happens in urban areas in West Sumatra. Art studio or artists working on Galombang dance by placing women as dancer trend is increasingly entrenched even the performing arts market wants to do so. This means that from the aspect of market value, the Galombang dance creation using women as performers are is more desirable compared to the Galombang dance with male as the dancers. Up to now, the trend of using female dancers is more dominant in the Galombang dance, and it still continues and entrenches in West Sumatra people.

\section{METHOD}

The data presented in this research was qualitative data. The data in this study was obtained by collecting various information from informants. Interviews were conducted to obtain data on women domination in the process and the performance of the Galombang dance. In addition, the re- 
searchers observed the behavior of artists, dance performances, and public response to the Galombang dance. The visual audio recording was done to complete the data field.

The data were analyzed ethnographically in which the researchers determined the various areas analyzed and the cultural theme. The analysis was also conducted on various components related to performances, artist behavior, issues of women domination in the Galombang dance performance. The validity of data was done by rechecking the data field, discussing with peers, doing triangulation, and testing the data by looking at the research context.

\section{RESULTS AND DISCUSSION}

\section{Women Domination in the Galombang Dance Creation Performance}

The Galombang Dance creation is a dance of Galombang that is laid out recently by the dance performers who are members of various performing arts performances in West Sumatra. From the aspect of usability and function, the Galombang dance creations is not much different from the traditional the Galombang dance cultivated by the Minangkabau people in various regions (nagari) in West Sumatra. The Galombang Dance is usually used for traditional and ceremonial events of the government. Today's Galombang dance creations are also used for the same thing, namely traditional ceremonial events and ceremonial events as well as for welcoming guests in various visits. However, in the form of performances and the composition of the actors (dancers and Caran bearers), there is a difference in the dance set of the Galombang creations.

Susmiarti (2015) says that the creative dance is a new dance form that composes old dances or creates dance with new ideas. The creative dance can be rooted in the well-established customary dance resources as well as dances cultivated a source of movement derived from the explorations of dancers' bodies and collaboration between explorations with previously exis- ting sources of motion. It means dance of the Galombang creations is a dance which is derived from the Galombang dance that already existed and became a cultural heritage of Minangkabau community in West Sumatra.

Waruwu (2015) states that the creative dance is an effort to develop a form of dance existed in which the goal is to adjust the existence of the dance with a new culture or new system prevailing in society. Furthermore, Indrayuda (2011) explains that dance, as a human product used by humans, rationally must be in line with the behavior patterns occur in humans in the same time with the existence of the dance. Thus, dance should be developed in quality from motion aspects, costume, music and space as well as in the way of performing it. Accordingly, the current Galombang dance has been transformed into a Galombang creative dance which is more dominated by female dancers as the performers.

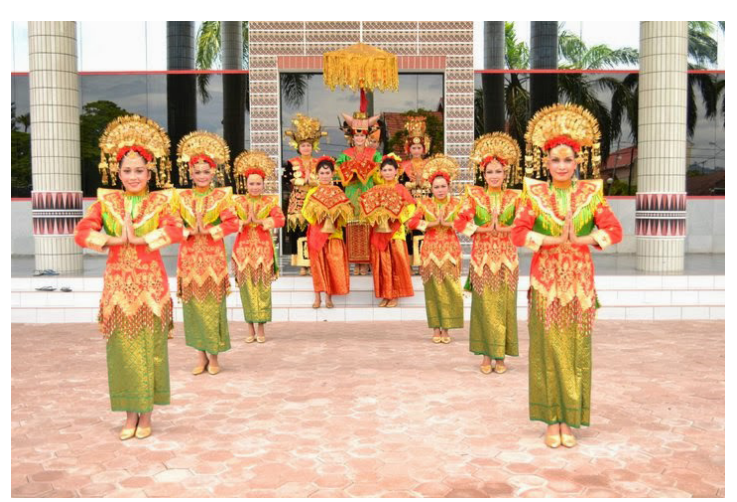

Figure 1. Female Activity in The Galombang Dance Creation (Estria 2016 Documentation).

Nowadays, the women dominance begins with dancer and Carano carrier. Even up to now the dominance of women is increasingly visible because sometimes the Galombang dance is performed without any male dancers in the composition. Although the male dancers are used in limited numbers, they are still involved in popular art galleries in West Sumatra, such as the Indojati, Syofiani and Satampang Baniah dance studio. 


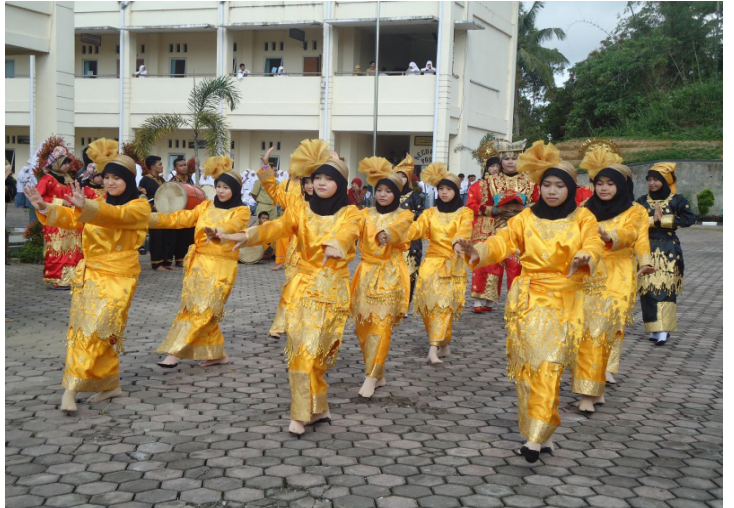

Figure 2. The Existence of Women in the Galombang Dance Performance (Estria 2016 Documentation)

Based on the researchers' observations at the Indojati Padang dance studio located in Taman Budaya West Sumatra Padang, the Galombang dance has never been shown without a male and female. It means that both dancers types are always performed in the Galombang dance production creations by Indojati studio production. The Galombang Dance creations are arranged by the choreographer of Indojati studio using male and female dancers.

The women existence in the Galombang dance performed by the Indojati studio choreographer was initially dominated by men. Then in the 1990s, according to Dasman Ori as the Chairman of the studio, the number of male dancers was somewhat reduced, and the Galombang dance creations were dominated by women. The number of male dancer rapidly declined, so more females were employed in Galombang dance performance.

Along with that, Filhamzah (interview on March 29, 2016) said that the existence of women in the Galombang dance cannot be left ignored at this time. Some studios currently, including Indojati, are dominated by female dancers as sometimes the consumer ask the Galombang dancers with beautiful women as the dancer. Due to the increasing number of female dancers in the Galombang dance, the longer the row or line of female dancers is arranged, the more impressive the dances and events are shown. In order to meet the de- mand, the number of female dancers are exceeded from male dancers.

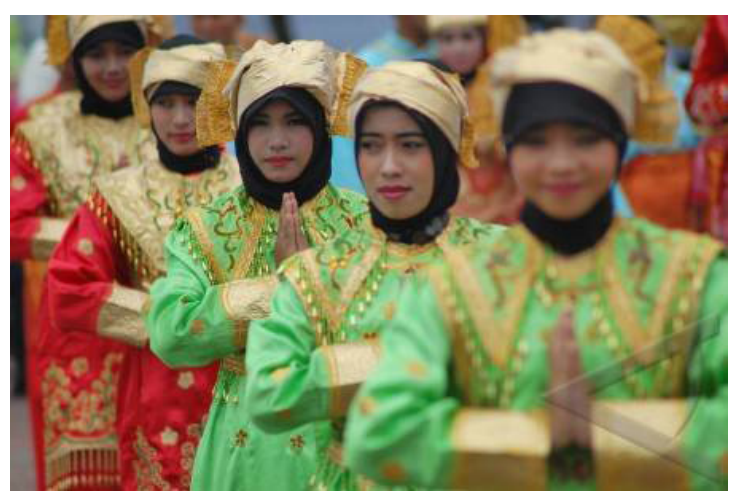

Figure 3. Galombang Dance from Female Dancers Junior Indojati (Estria 2016 Documentation)

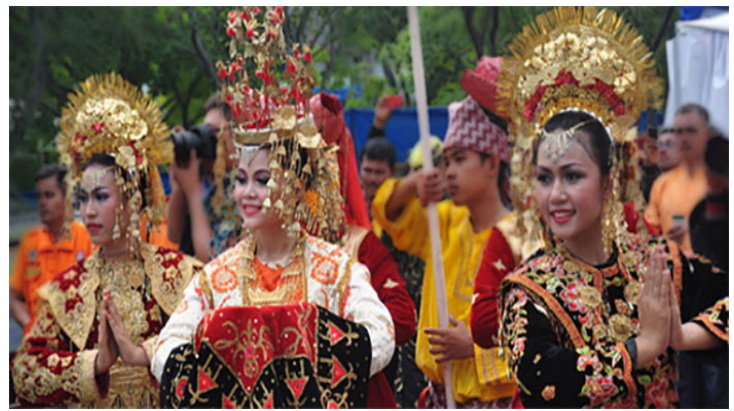

Figure 4. The existence of beautiful, graceful and glamor women in the Galombang Dance Creation as Carano Bearer (Estria 2016 Documentation)

After researchers observed the $\mathrm{Sa}$ tampang Baniah studio, the existence of women had a big influence in the Galombang dance performance. If there were no female dancers in the Galombang dance creation performance, the performance of Satampang Baniah Studio would fall in the consumers' eyes. According to Sulastri Andras, the leaders of the studio, the consumer asked to show a beautiful high female dancer in the Galombang dance performance. If Satampang Baniah studio does not display female dancers based on criteria demanded by the consumers, they will complain. Finally, the existence of male dancers increasingly marginalized in the performance of the dance Galombang creations.

Pujileksono (2009) exclaims that transformation involves changes in the social and the ecological web relationships. 
If the web structure is changed, there will be a values and thoughts transformation as well as the substance of a culture or art. Cultural transformation is related to the human culture evolution. This transformation is typically preceded by a social indicators variety. This cultural transformation is an essential step in the development of civilization. All civilizations run through growth and integrity process. It applies to the contemporary tradition dance from male domination to women domination as dancer.

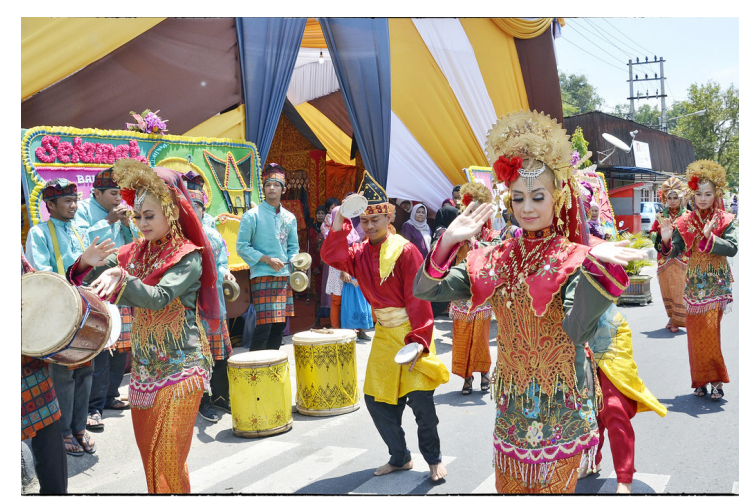

Figure 5. The Women Grace Performing the Dance Galombang At the Marriage Party in Padang City (Estria 2016 Documentation)

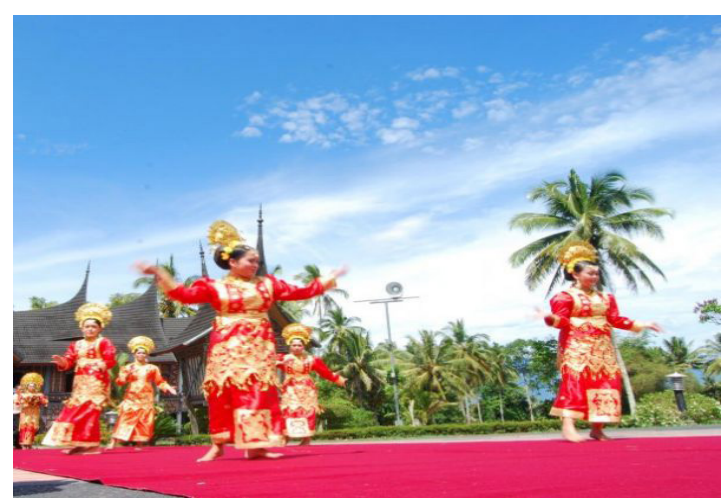

Figure 6. Women Activity Dominating the Galombang Dance Performance (Estria 2016 Documentation)

According to Maria Dance (interview on March 25, 2016), the activity of female dancers in the Galombang dance creations is as a dancer and a Carano bearer. Nevertheless, women also move as a carrier of flower bouquets as currently the Galombang dance creations not only bring Carano, but also use a flower bouquet for the welcomed or respected guests.

As Syofiani Bustamam said (interview on March 27, 2016) that the existence of women nowadays become the main actor in the Galombang dance performance. In addition, consumers prefer female dancers more than male dancers in the Galombang dance creations performances. The consumers logical reason is that the presence of female dancers represent various forms of color, variety and clothing style displayed. When the male dancers are more dominant, the costumes enjoyed by the audience is only one or two forms. Moreover, the Galombang dancers can also be used as a row of visitors (pagar ayu) in the wedding ceremony. In Minangkabau custom, it has eliminated the role of men as a protector of guests who come to attend the wedding party as usually they do it and form the configuration after dancing.

Based on the liberal feminism, Hidayat (2011) states that a freedom and equality rooted in rationality separating between private and public worlds. The framework of liberal feminism is to strive for equal opportunities and rights for every individual including women as the Galombang dancers, even becoming dominant today in the Galombang dance performances in West Sumatra.

The women emancipation in all aspects such as an equal education, equal skills and open access to jobs in which previously is only accessible to men is the change that eagerly wants to be achived by the liberal feminism. In this point, women can develop themselves in the public sphere by becoming professional dancers of the Galombang creations. Also, its existence is needed in the Galombang dance creations created by choreographers and by producers producing the dance.

The women existence in the Galombang dance creations do not get obstacles from various parties. It means that the women existence in performing or offerings the Galombang creations is not prohibited or no niniak mamak, pangulu, or community leaders in West Sumatra opposing the presence of women in the dance. 
According to Syofiani, Filhamzah, Dasman Ori, and Maria Dance, the existence of female dancers is not troubled by the consumers who use it. In addition, the affirmation made by Filhamzah (interview on March 28, 2016) stated that the activities of women in the Galombang dance production creations made by Indojati still give the appropriate movement for women. This means that the women activity as a dancer is in accordance with the women character. It is not like some other art studios which give women men's clothing with male motion characters.

The women existence and activity in the Galombang creative dance has spawned the Galombang dance performance at various events such as marriage feast, the reception of honorable guests in the inauguration of something, or in certain ceremonies and official government events. As women's activities still remain as women, they wear women's clothing with the movement of female characters when they play as dancers. This reality is presented by the three popular art galleries in $\mathrm{Pa}$ dang city at the present time. Women have become the icon of the current creation of the Galombang dance in the big cities of West Sumatra Province.

\section{The Women's Role in the Galombang Dance Creation Performance}

As seen in art galleries in Padang, Bukit Tinggi, and Padangpanjang, woman is the currently icon of dance creations in West Sumatra. In each of their dance productions, it seems that women are more dominant as dancers. Every dance production produced by art galleries in Padang always puts women in their dance work production. It was what researchers saw in the Galombang dance creations of Indojati, Syofiani and Satampang Baniah dance studio production in Padang. These three studio productions are popular art galleries in Padang city both past and present time.

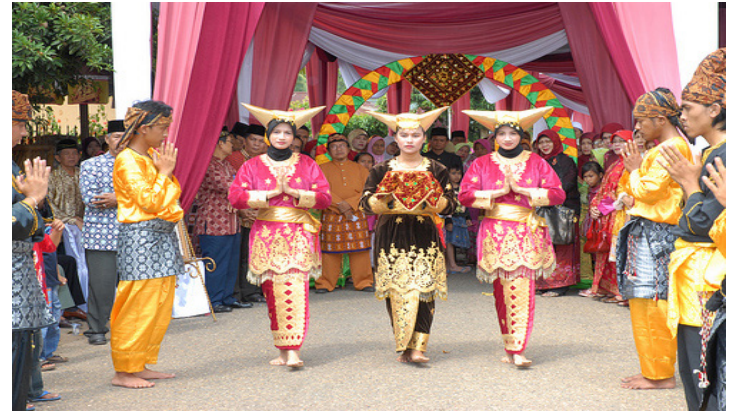

Figure 7. The Women Role as the key to the Galombang Dance Performance in Wedding Party Events (Estria 2016 Documentation)

The Galombang Dance produced by the three popular sanggar, Syofiani, Indojati and Satampang Baniah, never leave women in various performances. When researchers watched every event such as a wedding party regularly followed by the three studio productions, they never did it without the women dancers in the composition of dancers. It indicates that in the appearance of the Galombang dance creations, women have an important role.

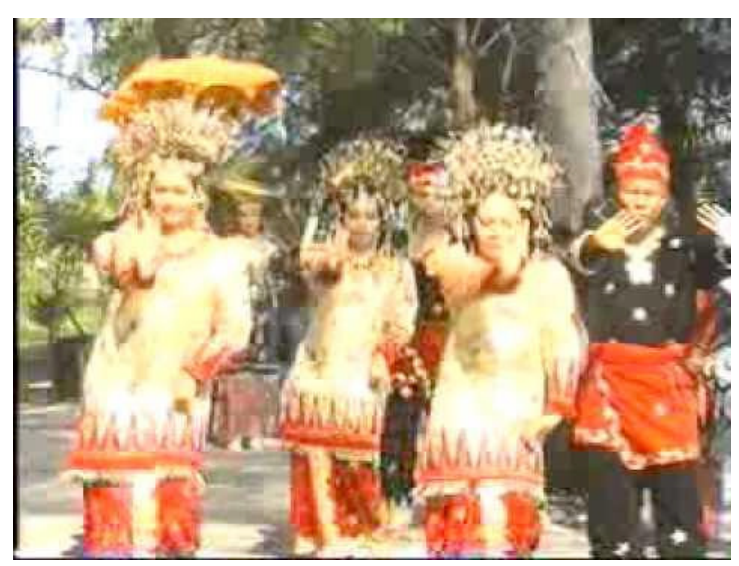

Figure 8. Woman as an Icon of the Galombang Dance in Indojati studio production, Padang

(Estria 2016 Documentation)

According to Suharti (2012), traditional dance such as in Banyuwangi which originally danced by male dancers, it is later danced by female dancers as the demand for the entertainment and the tourism industry interests. The women existence in the dance is used as a tourist attraction. Therefore, traditional dance in Banyuwangi such as Gandrung dance is packed for the benefit of tourism. 
Based on what the researcher observe so far, most consumers wanted a female dancer in the Galombang dancer creations nowadays in every appearance. It means that the existence of women in the Galombang dance is considered meaningful by the studio manager, choreographer, and art connoisseur as well as the consumer. Women act as the key to the Galombang Dance Performance and the key to the existence of these studio productions in receiving orders or requests from the consumer.

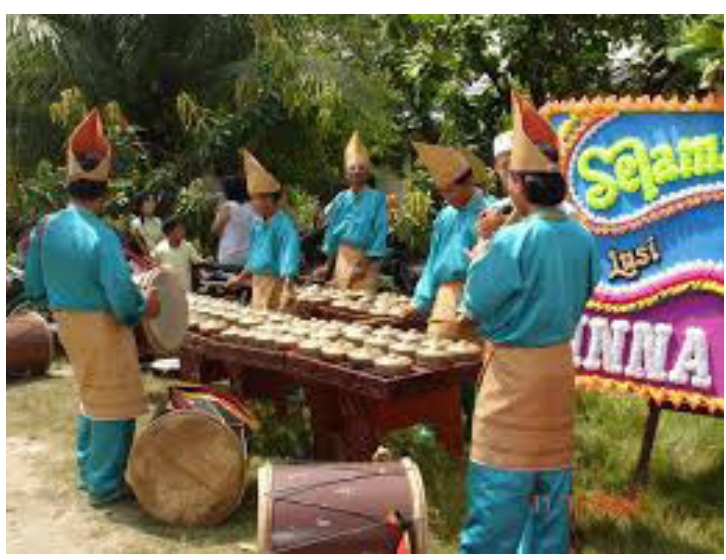

Figure 9. The Galombang Dance Musician (Estria 2016 Documentation)

As explained by Maria Dance (interview on March 26, 2016), the women role in THE Galombang dance creations can determine whether the dance received a good response from the consumer. It means that the discharge level of the Galombang dance by the consumer depends on the placement and the use of female dancers in the Galombang dance creations.

Damhuri (2013) explains that women can act as the key to the artistic and harmonization of a dance cultivation such as the Tauh dance in Rantau Pandan, and the Galombang dance in West Sumatra. It means that the women presence plays a role in determining the quality of an arts dance entertainment, therefore the harmony in the dance performance can be achieved. Considering women are as artistic appeal in Galombang dance, hence now the number of female dancers have increasingly dominated the Galombang dance performance in West Sumatra.

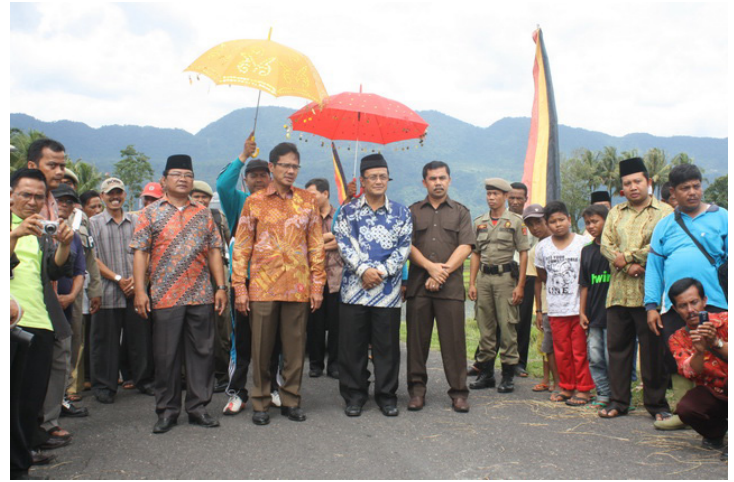

Figure 10. The Honorable Guest (Governor of West Sumatra) Welcomed by the Galombang Dance Performance (Estria 2016 Documentation)

As the consumer frequently order, women dancers in the dance Galombang performance with a more glamorous costume, the Galombang dance creations today more emphasis emphasizes on female dancers rather than on the dance movement or the purpose of the dance itself.

According to Maria Dance (interview on March 26, 2016), the women role in the Galombang dance creations today is termed as "kapalo galeh". It refers to the main actor in the Galombang dance creations performance. Besides, as the main character, female dancer is a trademark for studio producing the Galombang dance as the Galombang dance performance is more varied than when it only is used male dancers only.

Syofiani Yusaf (interview on March $28,2016)$ stated that the role of female dancers in the Galombang dance creations is as a marker to bundo kanduang participation in the dance performance. It means that women are linked to bundo kanduang who will awaits the guests. Furthermore, it symbolizes guests who are greeted by the Galombang dance are honored guests in which not only welcomed by the niniak mamak but also by bundo kanduang. Therefore, the role of female dancers is as a bundo kanduang welcome respected guests. Thus, now there has been a gender transformation from the aspect of the dancer's role in the Galombang dance creations.

Kuntowijoyo (2006) defines transfor- 
mation as a scientific concept or analysis tool to understand the world. The changes refers to at least two known conditions, pre-change and post-change circumstances. Transformation is an effort undertaken to preserve local culture in order to survive and be enjoyed by the next generation, therefore the cultural actors have a formidable character in accordance with the character desired by the state ideology.

Referring to Kuntowijoyo's statement, transformation is one way to preserve cultural heritage from extinction caused by the civilization change. Thus, the transformation of the male role dancers to women is an example of the change to continue the existence of the Galombang dance in life of today's Minangkabau society in West Sumatra. The reality shows that consumers prefer that the role of women is more dominant than men in the Galombang dance. When this market need is not fulfilled, it is estimated that the Galombang dance will be extinct in West Sumatra.

Transformation is a thing movement or shift to another or a new direction without changing the structure contained therein although its new form has changed. The framework of cultural transformation is the structure and culture, so even though it has transformed an art but its essence is still visible in the show. Although there has been a shift in the Galombang dance role, the displacement does not shift the role of the Galombang dance as a dance to honorable or glorified guests visiting a region or attending a special event (inauguration, marriage, and crowning).

The impact of the women existence as the main character in the Galombang dance creations creates a dilemma for the custom elite. While the community wants the women involved as dancers in the Galombang dance performance, ideally the Galombang dance is a dance intended for men, as the philosophy in which the existence of men is as a protector or fence (security) for a respected guest. When the women protecting the guests, it means that the women are protected creature. However, due to the rapid influence of the entertainment industry, traditional idealism has begun to be marginalized in West Sumatra.

The historical socio-historical changes from the traditional era, paternalistic into the capitalist era, and now into the era of technology give an impact on the institutions changing surrounding the art, including the institutions, the symbols referring to mystical symbols to realist symbols as well as obedience and communal change into individual norms. However, the era is still rooted in a clear root. When the people of West Sumatra have grown from agriculture to industry or commerce society, from communal to individual system, their point of view also towards dance also change. This means that dance began to shift from traditional to pop performing arts (Indrayuda, 2015). Thus, the women role as a major dancer in the $\mathrm{G} a$ lombang dance is very possible in the realm of a Popular dance in West Sumatra.

Iriani (2013) explains that today's dance works have collaborated between women's roles and dance styles for women and men. Iriani sees the facts in West Sumatra about Piring Syofiani dance. Both dance styles are collaborated in a single repertoire, therefore the identity of Syofiani dance works that has a serious character and weak graceful but firmly happens. Representing the illustration that women can balance the ability of male dancing techniques in agile motion, the mix between of men and women in one dance raises artistic value for the audience.

Erlinda (2012) says that women have transformed in her position as a Minangkabau woman with dancer as a profession. Previously, women were not allowed to dance which can be seen from various dance traditions that have become the cultural heritage of Minangkabau society. Today, as the existence of women as dancers has been a major actor in many dance creations, the role of women has marginalized the role of men as dancer creations in West Sumatra.

It turns out that the existence and role of women become the main focus in the Galombang dance creations today in 
Padang. Therefore, the art galleries such as Syofiani, Indojati and Satampang Baniah inevitably have to empower female dancer's role in the Galombang dance creations performance of their production. When women do not play a role in $\mathrm{Ga}$ lombang dance, it gives an impact on the Galombang dance value. It also affects the marginalization and the existence of art studio producing the Galombang dance creations.

Therefore, the existence of women and their role in the Galombang dance creations become important. Women become the figure needed by choreographer and dance studio at this time in Padang. The presence of women in the Galombang dance creations have an impact on the entertainment business and the existence of an art studio. It also affects the economic value for the studio.

\section{CONCLUSION}

The existence of women in Galombang dance cannot be abandoned in the Galombang dance performance. Some art galleries producing Galombang dance use more female dancers than male dancers. The women dominance is seen in various Galombang dance performances, both in the form of performances for traditional ceremonies of marriage as well as for ceremonial events of government and ceremonial customs in West Sumatra.

The women activities in the Galombang dance creations are almost in various sectors including dancers, carano carriers (betel plate), and companion of carano carriers (betel carriers). The female dancer existence and activity in the Galombang dance creations have a major influence on the quality or popularity and the usefulness of the dance in the community. It means that women are a benchmark against the use of dance by consumers.

The women existence and activity in the Galombang dance creations has have spawned the appearance of the Galombang dance creations at various events including a marriage party, the reception of honorab- le guests in the inauguration of something, certain banquet events and official events in various cities in West Sumatra. Women are the current icon of the Galombang dance creations in West Sumatra in which can be seen in art galleries in Padang, Bukit Tinggi and Payakumbuh.

The women dominance as dancers in the Galombang dance creations performance has marginalized the role of men as the main character in the Galombang dance. Ideally, it should be men who play an important role in the Galombang dance. However, women have currently replaced the role of men as the main character in the dance. It means that the women role in the Galombang dance is crucial to the profit and whether the Galombang creations is used by the consumer of Galombang dance service. Women act as the key to the Galombang dance value and the key to the existence of these studio productions in receiving orders or requests from the consumer.

\section{REFERENCES}

Damhuri, A., Darmawati, D., \& Yuda, I. (2013). Peranan Penari Perempuan dan Laki-laki dalam Pertunjukan Tari Tauh. Jurnal Sendratasik, 2(1), 7380.

Erlinda. (2012). Diskursus Tari Minangkabau di Kota Padang. Padangpanjang: Institut Seni Indonesia Padangpanjang.

Hidayat, R. (2011). Bias Gender Dalam Prestasi Akademik Siswa: Studi tentang Perbandingan Prestasi Akademik Siswa Laki-laki dan Perempuan di SMA 12 Bekasi. Jurnal Pendidikan dan Kebudayaan, 17(4), 37-49.

Indrayuda. (2009). Tari Balanse Madam Pada Masyarakat Nias Padang Sebuah Perspektif Etnologi. Padang: Universitas Negeri Padang Press.

Indrayuda. (2011). Perkembangan Budaya Tari Minangkabau dalam Pengaruh Sosial Politik di Sumatera Barat. Disertasi. Penang: Universiti Sains Malaysia.

Indrayuda. (2013). Tari Sebagai Budaya dan Pengetahuan. Padang: Universitas 
Negeri Padang Press.

Indrayuda. (2015). Tari Tradisional dalam Ranah tari Populer: Kontribusi, Relevansi, dan Keberlanjutan Budaya. Jurnal Humanus, 14(2), 14-27.

Indrayuda. (2016). The Existence of Local Wisdom Value Through Minangkabau Dance Creation Representation in Present Time. Harmonia: Journal of Arts Research and Education, 16(2), 143-152.

Iriani, Z. (2013). Gaya Tari Syofiani Sebagai Identitas Gaya Tari Baru Minangkabau di Kota Padang. Hasil penelitian tidak diterbitkan. Padang: Universitas Negeri Padang.

Iriani, Z. (2012). Dampak Keberadaan Tari Ilau dan Bentuk Penyajiannya dalam Masyarakat Salayo. Komposisi: Jurnal Pendidikan Bahasa, Sastra, dan Seni, 11(2), 47-59.

Jamal, E. (2011). Keberadaan Perempuan di Rumah Gadang. Padang: Yayasan Salimbado.

Kuntowijoyo. (2006). Budaya dan Masyarakat (Edisi Paripurna). Yogyakarta: Tiara Wacana.
Nerosti. (2013). Tari Galombang di Minangkabau Menuju Industri Pariwisata. Journal of Urban Society's Art, 13(2), 37-49.

Pujileksono, S. (2009). Antropologi. Malang: Universitas Muhammadiyah Malang Press.

Rinaldi, I. (2013). Betapa Penting Peran Perempuan di Minangkabau. Artikel di tulis dalam Kompas.com tanggal 14 Maret 2013.

Suharti, M. (2012). Tari Gandrung Sebagai Obyek Wisata Andalan Banyuwangi. Harmonia: Journal of Arts Research and Education, 12(1), 73-86.

Susmiarti. (2015). Model Pengembangan Pelestarian Tari Rantak Kudo di Nagari Lumpo. Hasil Penelitian tidak diterbitkan. Padang: Universitas Negeri Padang.

Waruwu, E. (2015). Peranan Perempuan dalam Tari Galombang Gaya Baru dalam Pesta Perkawinan di Kota Padang. Hasil penelitian tidak diterbitkan. Padang: Universitas Negeri Padang. 